\title{
Research on the Soft Power of Cross-border Language and Culture in the Core Area of the Belt and Road Initiative
}

\author{
Cailing $\mathrm{Xu}^{1 \text { a }}$
}

\author{
${ }^{1}$ School of Language and Culture \\ Chuxiong Normal University Chuxiong China \\ axucailing24680@163.com
}

\begin{abstract}
Language planning is a social governance activity that is both theoretical and practical and has an important position and role in the national development strategy. In the past five years, language planning research focusing on language topics of the "Belt and Road" is an academic focus formed by the Chinese linguistics community taking the initiative to pay attention to the major strategic needs of the country, and relatively rich research results have been achieved. Taking the application of language resources as the starting point, related research focuses more on the development of Chinese resources and the construction of foreign language resources in my country, and the exploration of minority language resources in China and the language problems they face is slightly insufficient. At present, the advancement of the construction of the core area of the "Belt and Road" has created a new language life between my country and neighboring Central Asian countries, highlighting the cross-border language phenomenon that deserves attention in the minority language life in Xinjiang's core area. The cross-border language in the core area condenses cross-border ethnic groups, carries multiculturalism, and is a unique national resource. The construction of my country's "One Belt and One Road", can play a multi-dimensional society such as international communication, national identity, economic support, and security maintenance. Features. However, at present, my country does not pay enough attention to the multi-resource value of cross-border languages in Xinjiang's core areas and lacks scientific and reasonable planning for them, which makes them unable to serve the social development and national strategy in an ideal manner. Therefore, in the context of the country's "One Belt, One Road" initiative, in the face of the ecological development trend of cross-border languages in the core area, how to develop its resource value, enhance its social function, and make it an element of building the language capabilities of the country's surrounding areas, etc. It has become a new topic in my country's language planning research, and my country's language planning practice serving the construction of the core area of the "Belt and Road" will inevitably face new situations and tasks.
\end{abstract}

Keywords: Linguistic ecology, "One Belt One Road" core area, cross-border language, Culture, Soft power

\section{INTRODUCTION}

In social language life, the practice of language planning at home and abroad has a long history, but the academic research on language planning has started relatively late. In the late 1950 s, foreign scholars in the field of sociolinguistics began to conduct special research on language planning, and experienced the linguisticoriented neo-classical period (late 1950s to early 1980s) and sociological-oriented After the period of criticism and disillusionment (from the early 1980s to the end of the 1980s), from the 1990s, it entered a period of renaissance of ecology-oriented disciplines. Chinese scholars have been involved in the field of language planning since the 1990s, and they have only more than 20 years of history.

Language is the country's soft power, so language planning is closely related to the country's development strategy. Language planning is not only affected and restricted by the national development strategy but also oriented to serve the national development strategy. From a global perspective, in the face of various important and major language issues, language opportunities and language challenges, Western developed countries have 
issued various guiding opinions and a series of measures in language based on national strategies. As far as China is concerned, the 2016 "Thirteenth Five-Year Development Plan for the National Language and Character Undertaking" (hereinafter referred to as the "13th Five-Year Plan" in the text) states that "strengthening international cooperation, promoting peaceful development, and safeguarding national interests and security." Especially the promotion of national strategies such as the construction of the "Belt and Road" [1], and new tasks have been proposed for enhancing the service guarantee capacity of language and writing undertakings and international exchanges and cooperation" [2], including strengthening language and national security, language identity and national identity research, strengthening language planning, language Research on text information technology, cross-border languages, etc., to improve language service capabilities, etc. Therefore, the "Belt and Road" national strategy not only puts forward new requirements for China's language planning work under the new situation but also provides new topics for current language planning research.

Based on the theme of this article, this chapter summarizes the past research results at home and abroad from the cross-border language soft power that serves the construction of the "Belt and Road". Focus on related research on cross-border language soft power, including language ontology research, language use research, language value research, language planning research, etc., and find research gaps in this field through analysis. After reviewing the research results of the abovementioned various fields respectively, we will make an overall outlook on the above-mentioned integrated research, leading to the research themes and research questions of this article.

\section{THE SOFT POWER BACKGROUND OF CROSS-BORDER LANGUAGES}

After more than 20 years of development, crossborder languages have gradually become an emerging research field of concern in today's linguistics circles. The results of Chinese cross-border language research were seen in collections of essays and various articles in the early days, but as the research deepened, a batch of academic monographs featuring case studies was gradually produced.

\subsection{Research on cross-border language ontology}

The domestic academic circles' ontology research on cross-border languages is mainly divided into the following three categories: the first category is the ontology research of cross-border languages in China; the second category focuses on the vocabulary, grammar, phonetics, and language styles of cross-border languages in China and abroad. The characteristics and variations are focused on the comparative study of language structure; the third category is the ontological study of overseas cross-border languages.

\subsection{Cross-border language use research}

With the development of language contact between various ethnic groups at home and abroad, many changes have taken place in the language use of Chinese crossborder languages. Therefore, many scholars in the field of ethnolinguistics have begun to conduct field investigations, based on the mastery of first-hand data, to study the use of cross-border languages in language life, so that the current situation of cross-border languages and their use can be increasingly clearly depicted and show. The domestic academic circles have relatively rich research results on the use of cross-border languages, mainly based on domestic and foreign case studies of cross-border languages. Among the domestic and foreign research results of domestic scholars, a series of books edited by Dai Qingsha is the representative. In terms of domestic research results, the Central University for Nationalities conducted more than 20 case studies on language use in ethnic minority areas across the country, and the results were compiled and assembled into a "series of studies on the use of Chinese minority languages in the new era" for publication.

\subsection{Research on the value of cross-border languages}

In the past ten years or so, among the research results of the domestic academic circles, the research on the resource value and social function of cross-border languages has made certain developments, and relevant applied research has gradually attracted attention.

In the research of domestic scholars, most of the related discourses run through the related topics of crossborder language application research, generally limited to point-to-point, and the results of special research are rare, and there are only a few articles.

The use of cross-border languages transcends national borders, and the existence of this phenomenon has pros and cons on international and bilateral relations between cross-border countries. Therefore, how to scientifically guide and correctly play the resource value and social functions of cross-border languages needs to arouse great attention from relevant state departments.

\subsection{Cross-border language planning research}

The above-mentioned research on the ontology, usage, and resource value of cross-border languages has laid the necessary foundation for the planning and research of cross-border languages and provided indispensable original materials. Currently, in the field of 
language planning and language policy research in China, some scholars have begun to study cross-border language planning. As a research field born out of the "One Belt, One Road" initiative, cross-border language planning research is expected to become a new academic hotspot. The academic community has conducted different dimensional researches on Chinese cross-border languages from the above perspectives, which not only shows us the current status of cross-border language research in the current period but also highlights the theoretical significance and application value of crossborder language research, laying a foundation for subsequent research. The foundation. Judging from the existing results of Chinese cross-border language research, there are still some issues worthy of further discussion.

First of all, most of the existing results have gathered research on cross-border language ontology and language use. There are relatively few special studies on the development of cross-border language resources, social functions, and other language planning subdivisions. The comprehensive and forward-looking research on crossborder language planning lack of. The study of Chinese cross-border languages is entering a critical period, but the current research results mainly focus on the discussion of language ontology, and there is a lack of research on its use function. The function of using crossborder languages relates to the status, ontology, and education of cross-border languages, while the development of cross-border language resources relates to cross-border language services. However, there are currently no research results on the status of cross-border languages in China's language order and language ecosystem, the training of Chinese cross-border language talents, and the development of cross-border language service industries. In other words, in addition to continuing research on cross-border language ontology and ontology planning in the future, research on crossborder language status planning, ontology planning, education planning, and service planning should be strengthened [3].

Secondly, in the use of regional cross-border languages, studies have paid more attention to crossborder languages in southern China, and less attention to cross-border languages in the north. From the perspective of natural conditions, the Xinjiang region is one of the areas where cross-border languages in northern China are relatively concentrated [4]. However, after consulting the literature, the author found that there is very little literature on cross-border language use research in Xinjiang. Under the important premise of language paving the "Belt and Road" construction, face up to an indepth consideration of the resource value of cross-border languages in the core area of the "Belt and Road" in the national development strategy, plan its social status, educational investment, and industrial development, etc., to make it in Playing its due social functions in language life at home and abroad should become an important content of China's "Belt and Road" language planning research [5].

\section{LANGUAGE AND CULTURE SOFT POWER THEORY}

In the context of globalization, language and culture have increasingly become an important part of a country's cultural soft power and even comprehensive national strength, which is inseparable from the cultural resource attributes of language. The concept of "soft power" was put forward by Joseph Nye of Harvard University in the early 1990s. He believes that the comprehensive national strength of a country includes not only the "hard power" shown by the economy, science and technology, and military strength but also the "soft power" shown by the attractiveness of language, culture, and ideology. For cross-border languages in the core area, because they are affected by the language environments of two or more bordering or neighboring countries, compared with the cultural attributes of non-cross-border languages, they often contain more special multiculturalism.

The formation of China's national language and cultural soft power theory is closely related to the international consensus on the value of language and culture and the domestic mission of cultural development At present, countries in the world have formed an international consensus on the national cultural value of language. In addition to representing culture, language can also construct culture. Language is the cultural resource of the country and has cultural value. Within China, the state emphasizes the need to promote the great development and prosperity of socialist culture. The report of the 18th National Congress of the Communist Party of China pointed out that to realize the great rejuvenation of the Chinese nation, it is necessary to strengthen the country's cultural soft power. As the national language of the people of all ethnic groups in China is a part of the Chinese national culture, the healthy development of its language ecology is crucial to the construction, development, and even prosperity of contemporary Chinese culture.

The construction of a community with a shared future for mankind not only relies on the participation and promotion of hard power such as economy and technology but also requires the support of soft power in language and culture. Culture has always been a bridge and ties for emotional communication between different countries and different nations, and cultural communication and blending is an important way for a country to communicate with other countries. In China, in ancient times, the "Silk Road" was a successful example of Chinese civilization going abroad and influencing the world. Today, there is the "Belt and Road" to shoulder the heavy responsibility of Chinese cultural dissemination. The cross-border language in the core area not only 
carries the cultural traditions of the cross-border ethnic groups but also undertakes the important task of spreading the profound and long-standing Chinese culture to the people of the countries along the route. It is an important resource for enhancing the soft power of Chinese culture. Secondly, the culture carried by the cross-border language in the core area is an indispensable part of the Chinese nation's culture, and it is an important part of the country's cultural soft power.

For cross-border languages in the core area, the cultural inheritance function and identity construction function, and other humanistic functions need to be realized and enhanced by maintaining its language vitality. Language is the product and carrier of national culture, as well as a component and concentrated expression of national culture. Therefore, the demise of a language, to a certain extent, represents the incompleteness and even disappearance of a culture. Especially for cross-border languages without text, the cultural inheritance depends on the survival and development of the cross-border language itself. For example, historically, the Tajik people in Xinjiang, China used their language to create a large number of narrative folk songs, custom folk songs, and singing and dancing folk songs. These folk songs have become an important medium for the Tajik people to express their happiness, anger, sorrow, ideals, and to narrate and record ethnic history. Therefore, a healthy and harmonious language ecology is an important guarantee for the development of cultural diversity.

The cultural undertakings of ethnic minorities are an important part of Xinjiang's "soft power" construction and also a "passport" for cultural exchanges between Xinjiang, China, and Central Asian countries. Therefore, the decline and disappearance of the cross-border language and cultural characteristics of the core area will inevitably affect the diversity of Chinese culture and weaken the cultural soft power required for China's "Belt and Road" construction. The intergenerational inheritance and value output of culture need the support of the power of education, and the play of this power must first be guaranteed through the implementation of educational planning and the issuance of educational policies. However, the current national language education policy in China takes more into consideration the promotion of the policy to the country's political stability and economic development, while it lacks consideration of safeguarding the national language and culture security and protecting the national cultural traditions. Therefore, maintaining the diversity of crossborder languages and cultures, developing the cultural value of cross-border languages, and enhancing the cultural soft power of the Xinjiang region and the country is one of the important tasks that need to be undertaken in the core area of cross-border language planning, especially in the field of education planning.

\section{CONCLUSION}

In the context of the One Belt One Road policy, the soft power and importance of cross-border languages have gradually emerged. From the perspective of the current national language planning goals, enhancing the national language strength, improving the national language ability, building a harmonious language life, serving the overall development of the society, and the overall national strategy constitute China's current language planning goals, and cross-border language planning for core areas in which the formulation and implementation of the company play an important leading role.

\section{REFERENCES}

[1] Xu W, Wu L, Duan X T, et al. Digital protection and inheritance of culture under the background of "The Belt and Road Initiative"[C]// 2016 IEEE International Conference on Electronic Information and Communication Technology (ICEICT). IEEE, 2016.

[2] Du M. Cross-Border M\&A Performance of Chinese Enterprises in the Context of the Belt and Road Initiative $[\mathrm{J}]$. Chinese Political Science Review, 2021:1-23.

[3] Dong Y. Language Competence and language Planning in "The Belt and Road Initiative"[J]. International Core Journal of Engineering, 2019, 5(12):119-124.

[4] Dai H. Study on the Cross-cultural Integration of Chinese Students in the Background of the "Belt and Road Initiative"[C]// 2018.

[5] $\mathrm{Mu} \mathrm{X}$. Research on the Cultivation of College Students' Confidence in Chinese Culture in College English Teaching under the Background of the Belt and Road Initiative[C]// 2019. 